ACTA AGROBOTANICA

Vol. 65 (2): 73-82

2012

\title{
EFFECT OF INCREASED COPPER ION CONTENT IN THE MEDIUM ON THE REGENERATION OF ANDROGENETIC EMBRYOS OF CARROT (Daucus carota L.)
}

\author{
${ }^{1}$ Urszula Kowalska, ${ }^{2}$ Katarzyna Szafrańska, ${ }^{1}$ Dorota Krzyżanowska, \\ ${ }^{1}$ Waldemar Kiszczak, ${ }^{1}$ Ryszard Górecki, \\ ${ }^{2}$ Krystyna Janas, ${ }^{1}$ Krystyna Górecka
}

\author{
${ }^{1}$ Department of Vegetable Crops, Institute of Horticulture \\ Konstytucji 3 Maja 1/3, 96-100 Skierniewice, Poland \\ ${ }^{2}$ Department of Ecophysiology and Plant Development, University of Łódź \\ Banacha 12/16, 90-237 Łódź, Poland \\ e-mail: ujkowalska@op.pl
}

Received: 07.09.2012

Abstract

The study was conducted to determine the effect of elevated concentrations of copper in the medium on the regeneration of androgenetic embryos of the carrot cultivar 'Kazan $F_{1}$ ' obtained in anther cultures and to determine the level of soluble phenols produced in the regenerates under copper stress. Green embryos were laid out on 4 regeneration media based on B5 medium ( $\mathrm{G}$ a m b org et al. 1968) without hormones, containing 0.1 - control, 1,10 , and $100 \mu \mathrm{M} \mathrm{CuSO}_{4} \times 5 \mathrm{H}_{2} \mathrm{O}$. The plant material was passaged 3 times, after 4, 9 and 15 weeks. During these passages the emerging structures were examined; they were classified in terms of growth and development in vitro, weighed and counted. The levels of soluble phenols in the freeze-dried regenerates were determined.

The elevated concentrations of copper in the regeneration media affected positively the formation of complete plants (rooted rosettes) and secondary embryos during the first 4 weeks of culture. After a longer regeneration time (9, 15 weeks), the elevated concentrations of copper caused negative effects: deformation of rosettes. After 15 weeks, the number of rooted rosettes decreased. The 9-week culture subjected to copper stress brought about an increase in the amounts of soluble phenols. The highest values were recorded in the rosettes treated with $10 \mu \mathrm{M} \mathrm{CuSO}_{4}$. Prolonged exposure to media containing elevated concentrations of $\mathrm{CuSO}_{4}$ caused a reduction in the accumulation of phenolic compounds in the rosettes.

Key words: $\mathrm{CuSO}_{4}$, deformation/deformities, phenols, in vitro, rosettes, stress

\section{INTRODUCTION}

Copper belongs to a group of heavy metals; it occurs naturally in trace amounts in the soil. As a result of the expansive nature of human activity, the natural environment becomes polluted and contaminated with heavy metals, including copper. The accumulation of copper in the soil is caused by over-fertilization of fields, the use of herbicides and pesticides, landfill disposal of municipal solid waste and sewage, and industrial pollution (Gruca-Królikowska and $\mathrm{W}$ a c $ł$ a w e k, 2006).

Copper is a micronutrient essential for normal growth and development of plants. It takes part in many physiological processes; it acts as an important cofactor for many enzymes in the processes of respiration, photosynthesis and the transport of electrons (Yruela, 2005).

An excess of copper and copper deficiency both lead to various disorders in plants, such as growth inhibition, decrease in biomass, and ultimately their death (Z e n k, 1996). At high concentrations, copper is highly toxic to all living organisms. Copper deficiency in higher plants manifests itself in the activation of morphological changes in the leaves and roots. Symptoms of deficiency appear in the early stages of plant development and are characterized by leaf deformity, chlorosis and even necrosis (M a r s c h n e r, 1995). 
As a redox metal, copper generates reactive oxygen species by the Fenton reaction, which can result in oxidative stress leading to the peroxidation of the lipids in cell membranes and damage to them, and can ultimately lead to cell death (Kováčik et al. 2008). For this reason, plants have developed a precise genetically-controlled mechanism for regulating copper levels within the cell (Lenartowicz, 2002). They produce various compounds, such as phenolic acids, flavonoids, polyamines and proline, which are known as antioxidants and anticarcinogens $(\mathrm{S} \mathrm{rok} \mathrm{a}$ and Ci s ow ski, 2003; G ór eck a et al. 2007; J a $\mathrm{n}$ a s et al. 2009).

Phenols play an important role in increasing the resistance to adverse environmental factors such as UV radiation, extreme temperatures, and also heavy metals. The antioxidant activity of phenolic compounds consists in, for example, their high capacity for chelating metal ions. Phenolic compounds can inactivate metal ions and in addition inhibit the formation of reactive oxygen species by the Fenton reaction ( $\mathrm{R} \mathrm{i} \mathrm{-}$ c e - E v a n s et al. 1997). Phenolic antioxidants inhibit the peroxidation of lipids (Millic et al. 1998). Since the presence of heavy metals can affect the accumulation of phenols in tissue, they become suitable candidates to act as biomarkers. These compounds can thus be used as indicators of early environmental stress before any morphological and structural damage appears (B i a łoń ska et al. 2007).

Many authors have observed in their studies a positive effect of higher concentrations of copper in in vitro cultures of various plant species. Elevated concentrations of copper have been found to increase the effectiveness of the formation of embryos and regenerates, and improve their quality. Such observations have been reported by Purnhause r and Gyulai (1993) in Triticum aestivum L. (wheat), (X Triticosecale Wittmack) (triticale) and Nicotiana tabacum $\mathrm{L}$. (tobacco); Tahili a n i and Koth ari (2004) in Triticum aestivum L. (wheat); D a h 1 e e n (1995) in Hordeum vulgare L. (barley); $\mathrm{S}$ a h raw at and $\mathrm{Ch}$ and (1999) in Oryza sativa L. (rice); N i rw a n and Ko th a r i (2003) in Sorghum bicolor L. (sorghum); K o thari et al. (2004) in Eleusine coracana L. (finger millet); Gori et al. (1998) in Nicotiana tabacum L. (tobacco); S a b a et al. (1999) in Lepidium (peppergrass); K u m a r et al. (2003) in Tinospora cordifolia and S in ha et al. (2010) in Withania somnifera L. (Indian ginseng).

There have also been reports of negative effects of elevated copper concentrations on in vitro regeneration: Purnhauser and Gyulai (1993) in Brassica napus L. and Nicotiana tabacum (L)., G or i et al. (1998) in Nicotiana tabacum (L.).
We are not aware of any reports on the effects of elevated copper concentrations on in vitro regeneration of carrot. The aim of this study was therefore to determine the effect of increased concentrations of copper (as sulphate) on the regeneration of androgenetic embryos of carrot cv. 'Kazan $\mathrm{F}_{1}$ ' and the levels of soluble phenols in the regenerated plant material.

\section{MATERIALS AND METHODS}

The starting material consisted of embryos of the carrot cultivar 'Kazan $\mathrm{F}_{1}$ ', made to turn green under continuous light and originating from anther cultures carried out according to the procedure developed by Gó re cka et al. (2005). They were transferred into test tubes onto 4 regeneration media: B5 medium by $\mathrm{G}$ a m borg et al. (1968) without amino acids and growth regulators, with $20 \mathrm{~g}$ sucrose, with $0.1 \mu \mathrm{M} \mathrm{Cu}-$ $\mathrm{SO}_{4} \times 5 \mathrm{H}_{2} \mathrm{O}$ (control), and its modifications with the copper content increased 10, 100, and 1000 times relative to the control. The doses of copper in the different media were as follows: control $-0.1 \mu \mathrm{M}, 1 \mu \mathrm{M}$, $10 \mu \mathrm{M}, 100 \mu \mathrm{M} \mathrm{CuSO}_{4} \times 5 \mathrm{H}_{2} \mathrm{O}$. The $\mathrm{pH}$ of the media was adjusted to 5.8 .

There were 20 carrot embryos laid out on each medium ( 1 embryo per 1 test tube). The test tubes were placed in a breeding room at a temperature of $+20^{\circ} \mathrm{C}$, with a photoperiod of $16 \mathrm{~h}$ illumination at about $30 \mu \mathrm{mol} \times \mathrm{m}^{-2} \mathrm{sec}^{-1}$ and $8 \mathrm{~h}$ darkness. Three passages of the obtained material were carried out, after 4, 9 and 15 weeks of culture. The experiment was conducted in 10 replicates ( 1 replicate $=1$ test tube). The following categories of the obtained structures were distinguished: green incipient rosettes, normal rosettes without roots, normal rooted rosettes, unrooted rosettes with a callus heel, rooted rosettes with callus separating the root from the shoot, and secondary embryos. The obtained plant material was counted and weighed.

Some of the multiplied plant material for use in further studies was transferred into 20 test tubes with a fresh medium of the same composition.

It was a univariate experiment. The results were analyzed statistically. Mean values were assessed with an analysis of variance using the Newmann-Keuls test at a significance level of a $\leq 0.05(5 \%)$.

\section{Determination of soluble phenols}

After counting and weighing, the obtained plant material was collected and frozen at a temperature of $-80^{\circ} \mathrm{C}$, and then subjected to the process of freeze drying. To determine the levels of soluble phenols, a spectrophotometric method was used, developed by Johanson and Shaal (1957) and modified by Singelton and Rossi (1965). 
The freeze-dried carrot samples with elevated levels of copper and the control were placed, about $30 \mathrm{mg}$ in each case, in test tubes containing $3 \mathrm{ml}$ of $96 \%$ ethanol. The samples, tightly closed, were immersed for 2 minutes in a boiling water bath. After cooling, the tissue was homogenized in a chilled porcelain mortar. The homogenate was then centrifuged for $10 \mathrm{~min}$. at $4000 \times g$ using a centrifuge (3K30, Sigma), and after centrifugation the resultant supernatant liquid was placed at $+4^{\circ} \mathrm{C}$ in the dark. After 24 hours, the extract was supplemented with $80 \%$ ethanol to the original volume $(3 \mathrm{ml})$ and treated as the source of soluble phenols. The test samples containing $0.5 \mathrm{ml}$ of extract, $3.65 \mathrm{ml}$ of distilled water and $0.1 \mathrm{ml}$ of the Folin-Ciocalteu reagent were mixed thoroughly; after 3 minutes, $1 \mathrm{ml}$ of $10 \%$ $\mathrm{Na}_{2} \mathrm{CO}_{3}$ was added; the samples were mixed again and left in the dark for 60 minutes. Because the extracts were coloured (the tissue contained chlorophyll), a blank sample was prepared for each of them, which instead of the Folin-Ciocalteu reagent contained an extra $0.1 \mathrm{ml}$ of distilled water. After 1 hour, absorbance was measured at a wavelength of $1=660 \mathrm{~nm}$ with a spectrophotometer (U-2001, Hitachi), and the total phenolic content was read off the standard curve prepared on the basis of known concentrations of gallic acid.

\section{RESULTS}

In the first passage, 4 weeks after setting up the cultures, there was a positive effect of the increased concentrations of copper on the effectiveness of the regeneration of androgenetic embryos. Normal, rooted rosettes, i.e. complete plants, formed in greater numbers on the media with increased copper content than on the control medium (Fig. 4). The highest number of them per 1 embryo, 7.4, weighing 0.190 grams, was obtained on the medium with a 100 times higher concentration of $\mathrm{CuSO}_{4}$ (Figs 1a, 2a). About half as many rosettes formed on the control medium. The highest number of green incipient rosettes from one embryo, 1.3, was also obtained on the medium with a 100 times higher copper content (Fig. 1a). Their weight was 0.013 grams (Fig. 2a). In the initial phase of the development of androgenetic embryos on the regeneration media, yellow crumbling structures, so-called secondary embryos, were formed, which in later stages turned into rosettes. The increased concentrations of $\mathrm{CuSO}_{4}$ also contributed to the formation of secondary embryos. In the first passage, after 4 weeks of culture, the largest number of these structures from 1 test tube (13.2), weighing $0.023 \mathrm{~g}$, was found on the medium with $1 \mu \mathrm{M} \mathrm{CuSO}_{4}$, fewer (5.1) from the tube on the medium with $10 \mu \mathrm{M} \mathrm{CuSO}_{4}$, whereas on the control medium there were only 2.4 such embryos per 1 test tube.

In the second passage, the 100 times higher copper content in the medium continued to positively influence the formation of complete plants. From 1 test tube, 3.7 rooted rosettes were obtained, weighing $0.229 \mathrm{~g}$, while in the control 2.6, weighing $0.236 \mathrm{~g}$ (Figs 1b, 2b). With the increase in copper concentration, the number and weight of the resulting green incipient rosettes decreased. There was also an adverse effect of the elevated concentrations of copper on the formation of unrooted rosettes with callus at the base. About 3 times more of them were found on the medium with 1 and $10 \mu \mathrm{M} \mathrm{CuSO}_{4}$ than on the control medium. Although rooted rosettes with the root separated from the shoot by callus were obtained on each of the analyzed media, the highest number of them (1.8), weighing $0.416 \mathrm{~g}$, was recorded on the medium with $1 \mu \mathrm{M} \mathrm{CuSO}_{4}$ (Figs 1b, 2b).

In the third passage, i.e. 15 weeks after the androgenetic embryos of carrot had been laid out on the different media, the increased levels of copper began to show a negative effect on the number of complete plants. The highest number of them from 1 test tube (7.3), weighing $0.152 \mathrm{~g}$, was obtained on the control medium (Figs 1c, 2c). On the medium containing $10 \mu \mathrm{M} \mathrm{CuSO}_{4}, 5.5$ rooted rosettes were obtained per 1 test tube, weighing $0.172 \mathrm{~g}$. However, incipient rosettes were most numerous on the medium with $1 \mu \mathrm{M}$ $\mathrm{CuSO}_{4}-4.2$ against 2.9 in the control combination. The prolonged action of the media with higher $\mathrm{Cu}$ concentrations caused an increase in the number of unrooted rosettes with a callus heel. The highest number of them was found on the medium with $1 \mu \mathrm{M} \mathrm{CuSO}_{4}$ -2.9 , weighing $0.158 \mathrm{~g}$ (Figs 1c, 2c).

The 100 times increase in $\mathrm{Cu}$ concentration in the medium in the 4th week of culture did not have a significant effect on the amount of soluble phenols in tissues and decreased it only slightly (Fig. 3). In the combinations with 1 and $100 \mu \mathrm{M} \mathrm{CuSO}$, too small amounts of plant material were collected to enable their analysis.

After 9 weeks, the lowest levels of soluble phenols were found in the rosettes growing on the medium supplemented with $1 \mu \mathrm{M} \mathrm{CuSO}_{4}$. In all the other variants, the amount of these compounds increased, and in the case of the concentration of $10 \mu \mathrm{M} \mathrm{CuSO}_{4}$ it reached a value twice as high as that after the first passage.

The levels of soluble phenols decreased markedly in all the analyzed variants after 15 weeks (third passage), but the rosettes treated with $10 \mu \mathrm{M} \mathrm{CuSO}_{4}$ still accumulated the highest amount of these compounds (Fig. 3). 
Fig. 1a Passage I

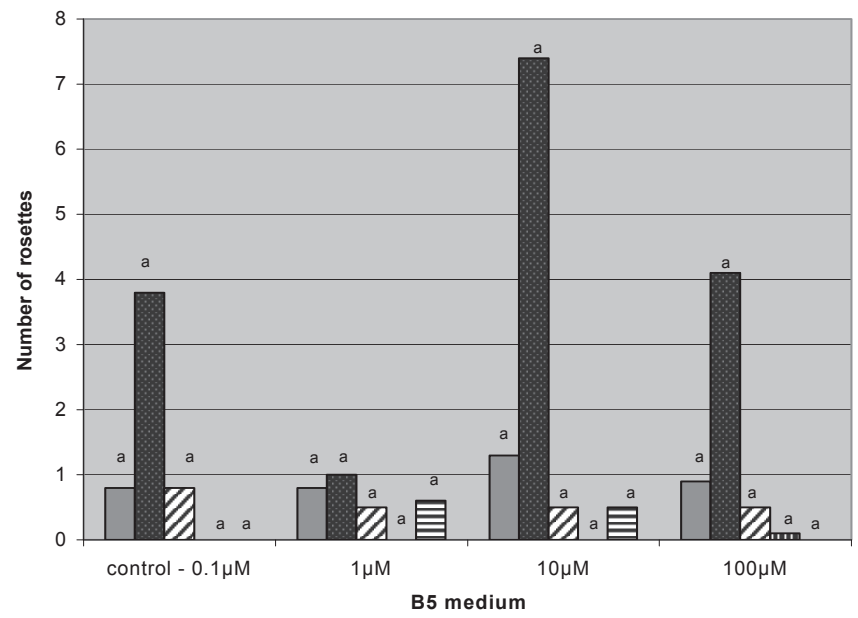

$\square$ green incipient rosettes

rooted rosettes

च rooted rosettes separated from shoot by callus

田unrooted rosettes

Bunrooted rosettes with heel

Fig. 1b Passage II

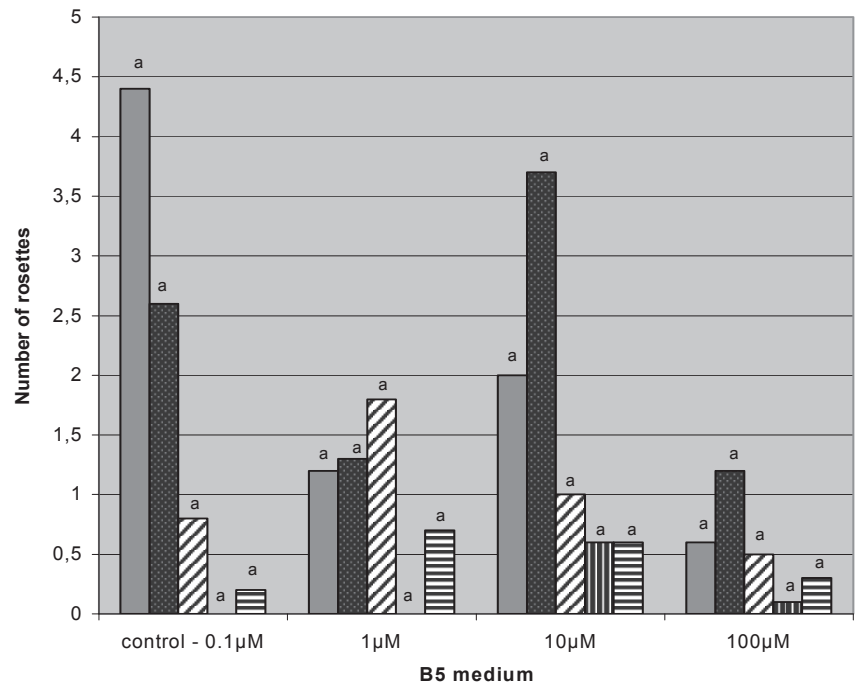

$\square$ green incipient rosettes

圆 rooted rosettes

a rooted rosettes separated from shoot by callus

田 unrooted rosettes

छunrooted rosettes with heel

Fig. 1c Passage III

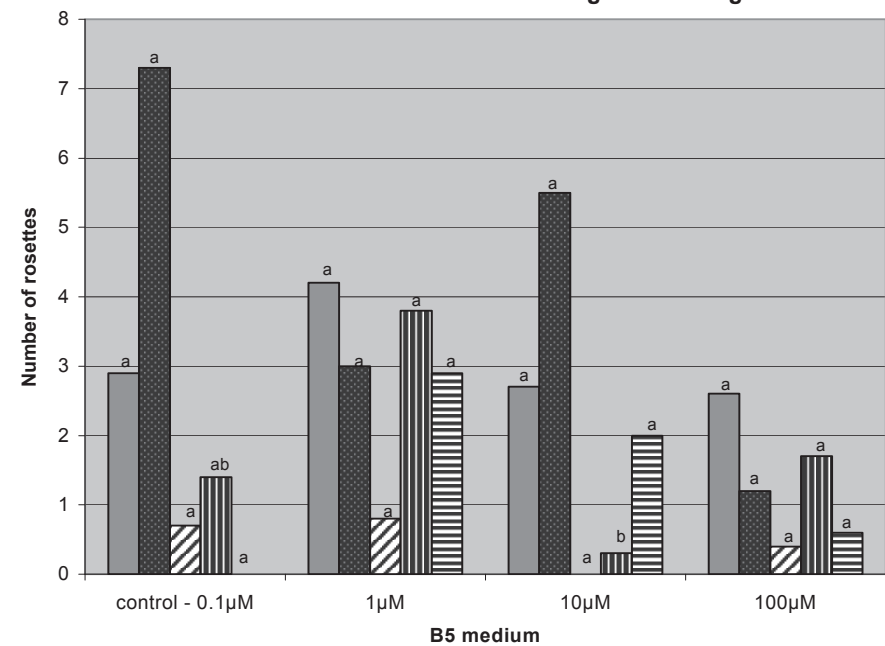

口green incipient rosettes

뭄rooted rosettes

arooted rosettes separated from shoot by callus

由unrooted rosettes

Eunrooted rosettes with heel

Fig. 1. Effect of elevated copper sulfate content in the medium on the number of rosettes regenerated on androgenetic embryos of carrot cv. 'Kazan $\mathrm{F}_{1}$ '

Fig. 1a - Passage I; Fig. 1b - Passage II; Fig. 1c - Passage III

It was a univariate experiment. Mean values were analyzed using the Newman-Keuls test at a significance level of $\alpha \leq 0.05$ $(5 \%)$. 


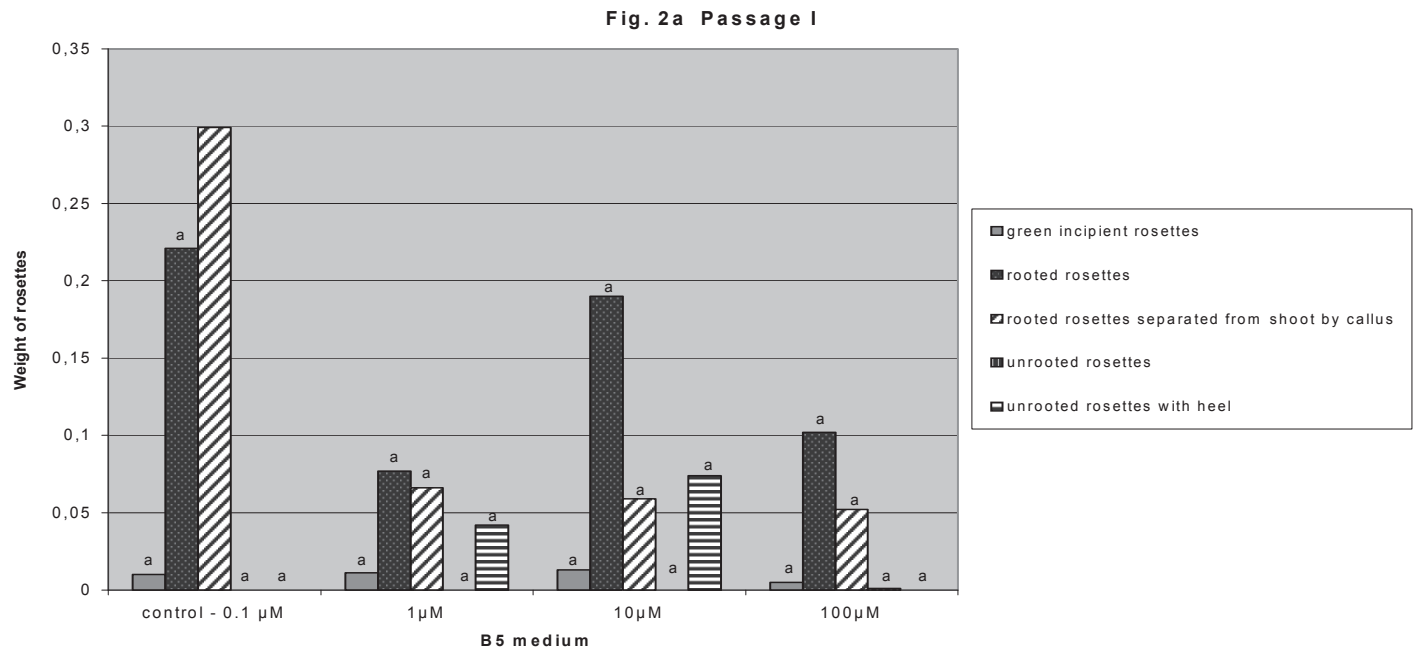

Fig. 2b Passage II
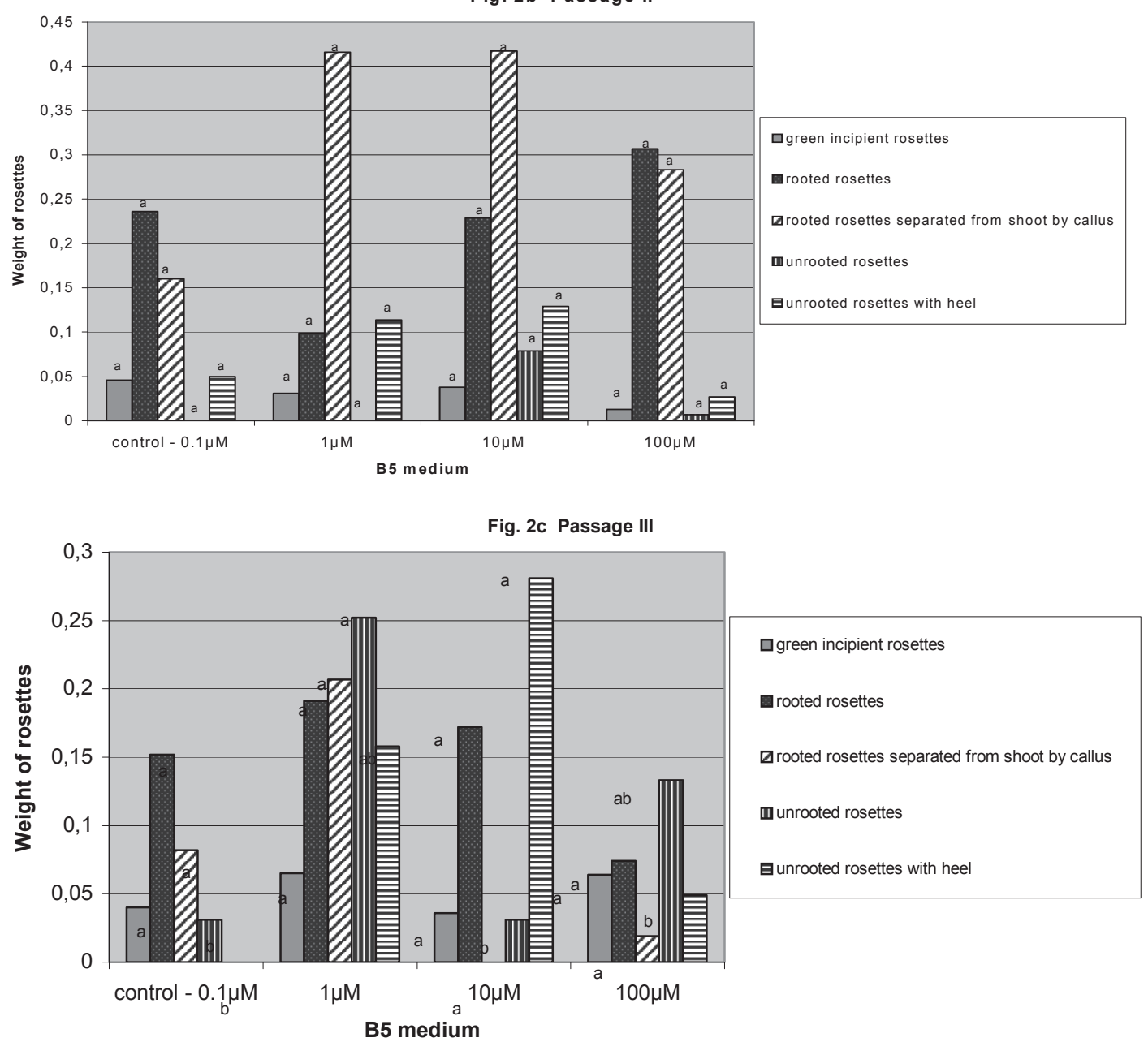

Fig. 2. Effect of elevated copper sulfate content in the medium on the weight of rosettes regenerated on androgenetic embryos of carrot cv. 'Kazan $\mathrm{F}_{1}$ '

Fig. 2a - Passage I; Fig. 2b- Passage II; Fig. 2c-Passage III

It was a univariate experiment. Mean values were analyzed using the Newman-Keuls test at a significance level of $\alpha \leq 0.05$ (5\%). 


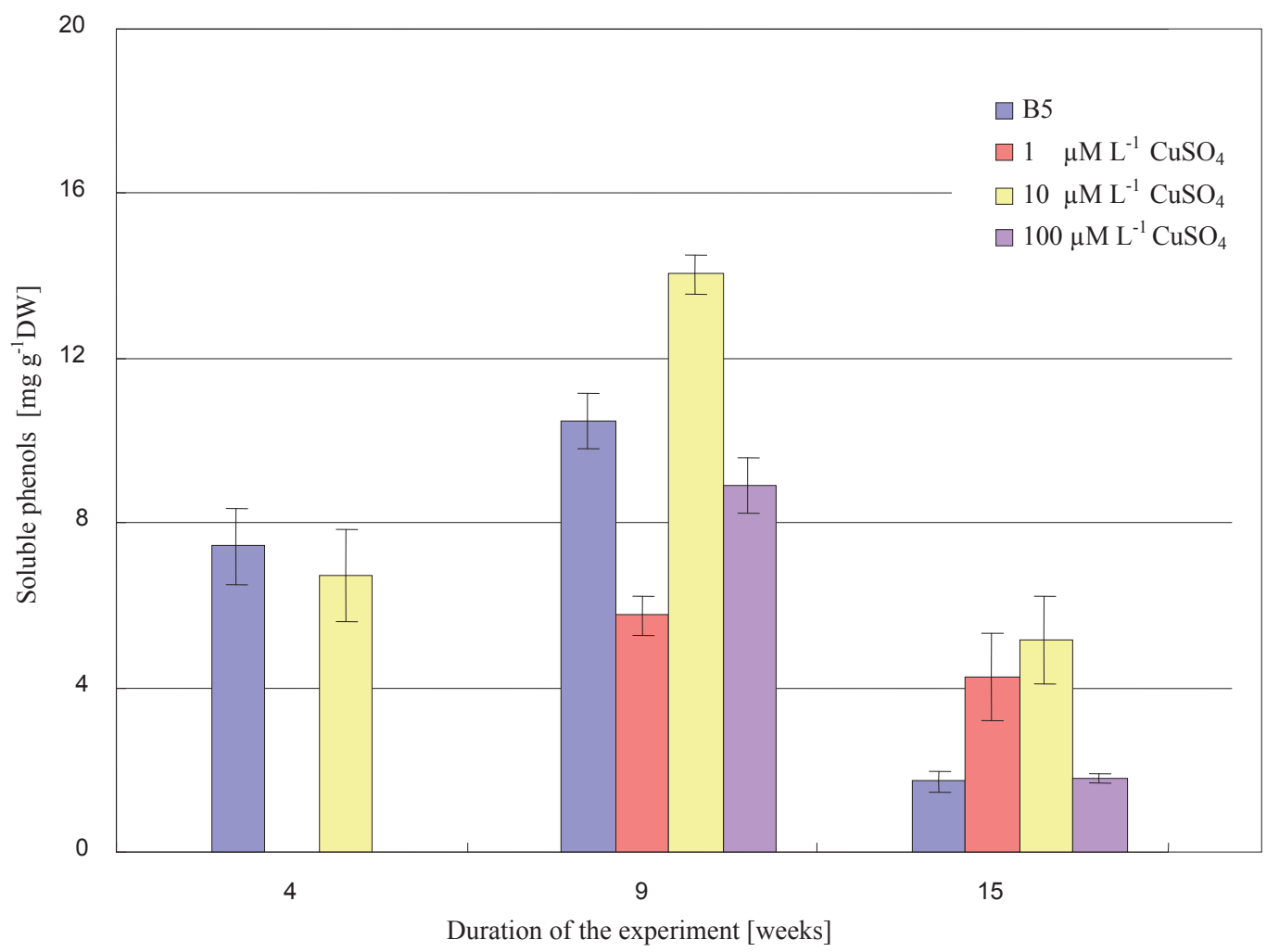

Fig. 3. Changes in the levels of soluble phenols in the rosettes of the carrot cultivar 'Kazan $\mathrm{F}_{1}$ ' treated with various concentrations of $\mathrm{CuSO}_{4} \times 5 \mathrm{H}_{2} \mathrm{O}$ for 4,9 and 15 weeks.

Control plants were grown on $\mathrm{B}_{5}$ medium with $0.1 \mu \mathrm{M} \mathrm{CuSO}_{4}(\mathrm{G}$ a m b o r g et al. 1968).

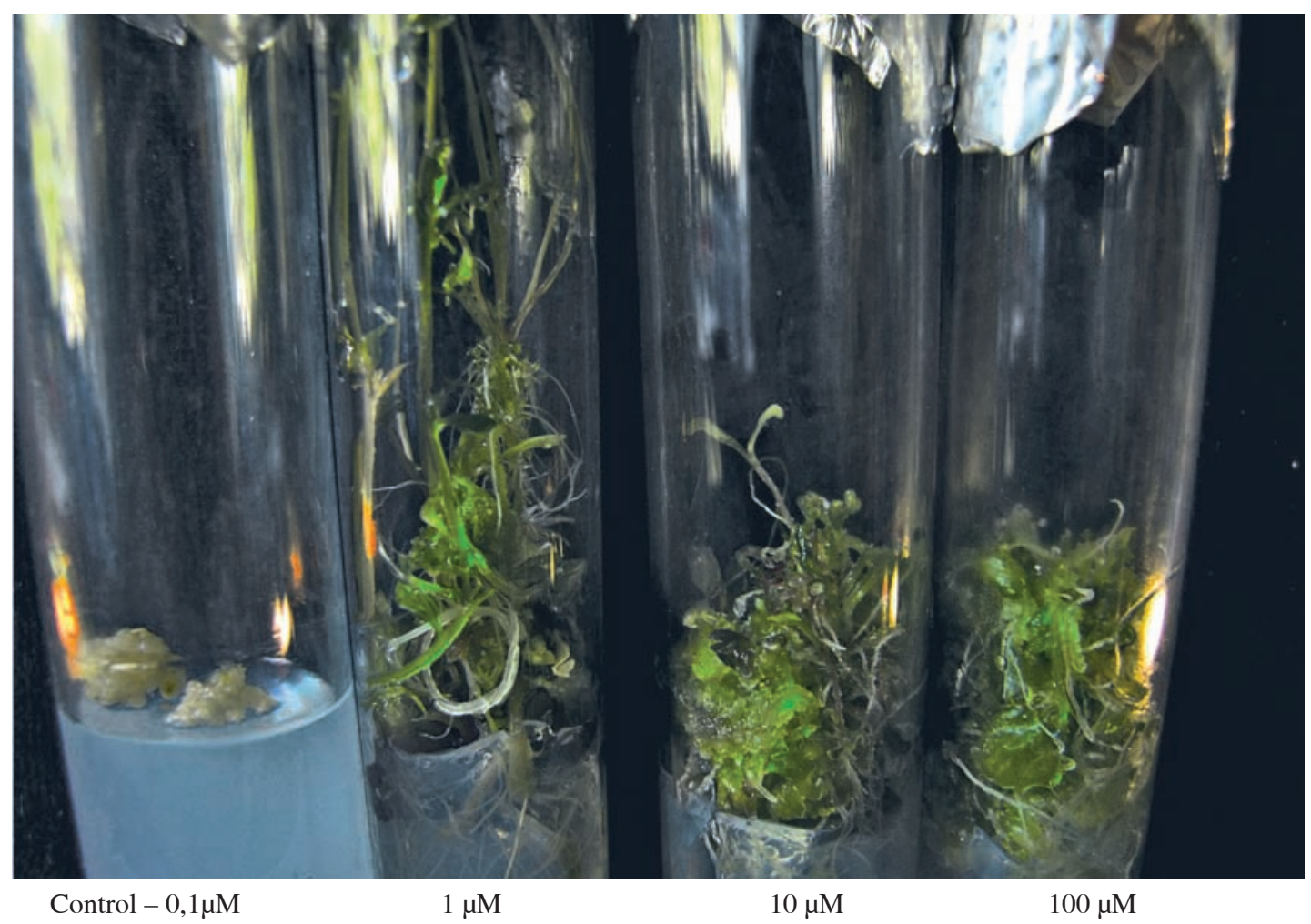

Fig. 4. Regeneration of androgenetic embryos of carrot, cv. Kazan $\mathrm{F}_{1}$, after for 4 weeks on medium with various concentrations of $\mathrm{CuSO}_{4} \times 5 \mathrm{H}_{2} \mathrm{O}$ 


\section{DISCUSSION}

The beneficial effects of elevated concentrations of copper in in vitro cultures have been emphasized by a number of authors. At higher concentrations of $\mathrm{CuSO}_{4}$, Purnhauser and Gy ulai (1993) observed significant growth of shoots regenerated from androgenic callus in Triticum aestivum L. (wheat) and $\mathrm{X}$ Triticosecale Wittmack (triticale). They also showed that the increased copper content in the medium for regeneration also had an effect on increasing the plant survival rate at the adaptation stage. Tahili a $\mathrm{ni}$ and Kothari (2004), to improve regeneration from wheat callus, used culture media with increased $\mathrm{CuSO}_{4}$ content in two lines, C-306 and R-3777. As little as $0.5 \mu \mathrm{M} \mathrm{CuSO}_{4}$ had an effect on improving the induction of callus from immature embryos and the regeneration of plants. Based on his research, D a hl e e n (1995) concluded that the concentration of $\mathrm{CuSO}_{4}$ in the standard MS medium is not optimal for callus cultures of Hordeum vulgare L. (barley) and that regeneration can be improved by using higher concentrations of copper. In rice, Oryza sativa L., increased concentrations of copper played an important role in improving its regeneration. The concentrations of 10 and $50 \mu \mathrm{M} \mathrm{CuSO}_{4}$ in $\mathrm{MS}$ medium had a beneficial effect on the regeneration of plants from immature embryos in two Indian rice cultivars $(\mathrm{S}$ a h raw at and Chand, 1999). W ojnarowie z et al. (2002) claim that the concentration of copper in the medium is an important factor affecting in vitro androgenesis in cereals. In liquid media for isolated microspore cultures of barley, increased copper content can initiate the development of green plants in frequently occurring albino lines, thereby strengthening the viability of the plant material obtained in the process of regeneration. Jos hi and Kothari (2007) reported that elevated concentrations of copper in the medium had a positive effect on the induction of shoot buds and their further development from cotyledon explants of Capsicum annиuт (L.). On a medium with $3 \mu \mathrm{M} \mathrm{CuSO}_{4}, 41$ shoots were obtained from 1 explant, and 17 of them were more than $2 \mathrm{~cm}$ in length.

In the study presented here, the increased concentrations of copper stimulated the formation of normal rooted rosettes during the first 4 weeks of culture.

There have also been reports in various species of adverse effects of elevated concentrations of copper in the induction of embryos and their regeneration. Researchers have also shown differences in the response of the tested species to the applied concentrations of $\mathrm{CuSO}_{4}$. Purnhauser and Gy ulai (1993) reported that $\mathrm{CuSO}_{4}(0.1-100 \mu \mathrm{M})$ had no significant effect on the morphogenesis of callus cultures of Brassica napus (L.). Higher concentrations of copper did not improve the regeneration of shoots, and the highest concentration $(100 \mu \mathrm{M})$ completely inhibited their regeneration and resulted in reducing the number of roots. G or i et al. (1998) observed in the tobacco variety Bel W3 that $50 \mu \mathrm{M} \mathrm{CuSO}_{4}$ considerably inhibited the growth of callus and the regeneration of shoots after one month of culture. In the presence of $100 \mu \mathrm{M}$ and $150 \mu \mathrm{M} \mathrm{CuSO}_{4}$, the fresh matter content decreased substantially. $200 \mu \mathrm{M} \mathrm{CuSO}_{4}$ almost completely inhibited the growth of callus. Copper concentrations higher than in the standard medium in longer-lasting cultures had a negative effect on the regeneration of androgenetic embryos of carrot cv. 'Feria $\mathrm{F}_{1}$ ' ( $\mathrm{Ko}$ w a l s k a et al. 2009).

Also in our study, we found that a longer exposure of the cultures on the media with elevated concentrations of copper resulted in deformities and adversely affected the number of rooted rosettes.

Research has been conducted on the mechanism of action of heavy metals, including copper, on living organisms. It shows that heavy metals may directly affect life processes of plants, their growth, development and aging, or indirectly through the production of jasmonates and ethylene (M a k s y mi e c, 2007).

The production of phenolic compounds can play a very important defensive role under copper stress. Similar results have been observed in suspension cultures of ginseng roots of Panax ginseng C.A. Mayer (A li et al. 2006), gibbous duckweed Lemna gibba L. (B a bu et al. 2003), in the material regenerated from embryos obtained from anther cultures of carrot Daucus carota L. cv. 'Narbonne $\mathrm{F}_{1}$ ' (G ó r e c k a et al. 2007), and in cultures of chamomile Matricaria chamomilla L. (K o vá č i k et al. 2008).

In our experiment, in the 9th week of culture, the lowest level of soluble phenols was observed in the regenerated rosettes on the medium with $1 \mu \mathrm{M} \mathrm{CuSO}_{4}$. In other variants, the amount of these compounds increased markedly, and in the case of $10 \mu \mathrm{M} \mathrm{CuSO}_{4}$ it reached a value twice as high as that after the first passage.

As reported by $\mathrm{J}$ a h a $\mathrm{n}$ g i r et al. (2008), plants under the influence of stress caused by the action of heavy metals produce secondary metabolites, whose number increases with the concentration of the metal, but only to a certain point, beyond which a decrease in these metabolites can be observed.

In the present study, after 15 weeks of culture, the amounts of soluble phenols decreased markedly in all the analyzed variants. It seems that in this case such a situation might have been expected, and the prolonged period of stress caused a fall in the levels of soluble phenols; nevertheless, in all the passages the rosettes treated with $10 \mu \mathrm{M} \mathrm{CuSO}{ }_{4}$ accumulated the largest amounts of phenolic compounds. 


\section{CONCLUSIONS}

Increased concentrations of copper had a positive effect on the formation of rooted rosettes during the first 4 weeks of culture.

After a longer regeneration time (9, 15 weeks), the elevated concentrations of copper caused negative effects, such as deformations of rosettes.

A 9-week culture on media with increased concentrations of copper had an effect on increasing the levels of soluble phenols. The highest values were recorded in the rosettes treated with $10 \mu \mathrm{M} \mathrm{CuSO}_{4}$.

Prolonged exposure to media containing increased concentrations of copper caused a reduction in the accumulation of phenolic compounds.

\section{Acknowledgements}

The experiments was conducted as part of the Multiannual Programme - Task 6.10 'Obtaining vegetable populations resistant to adverse abiotic factors using anther cultures and microspore cultures'.

\section{REFERENCES}

Ali M.B., Singh N., Shohael A.M., Hahn E.J., Paek K-Y., 2006. Phenolics metabolism and lignin biosynthesis in root suspension cultures of Panax gingeng in response to copper stress. Plant Sci. 171:147154.

Babu T.S., Akhtar T.A., Lampi M.A., Tripuranthakam S., Dixon D.G., Greenberg B.M., 2003. Similar stress responses are elicited by copper and ultraviolet radiation in the aquatic plant Lemna gibba: implication of reactive oxygen species as common signals. Plant Cell Physiol. 44:1320-1329.

Białońska D., Zobel AM., Kuraś M., Tykarska T., Sawicka-Kapusta K., 2007. Phenolic Compounds and Cell Structure in Bilberry Leaves Affected by Emissions from a $\mathrm{Zn}-\mathrm{Pb}$ Smelter. Water Air Soil Pollut. 181:123-133.

Dahleen L.S., 1995 Improved plant regeneration from barley callus cultures by increased copper levels. Plant Physiol. 78:4-7.

Gamborg O.L., Miller R.A., Ojima K., 1968. Nutrient requirements of suspension culture of soybean root cells. Exp. Cell Res: 151-158.

Gori P., Schiff S., Santandrea G., Bennici A., 1998. Response of in vitro cultures of Nicotiana tabacum L. to copper stress and selection of plants from $\mathrm{Cu}-$ tolerant callus. Plant Cell Tiss. \& Org. Cult. 53:161-169.

Górecka K., Krzyżanowska D., Kiszczak W., Górecki R., 2005. Embryo induction in anther culture of Daucus carota L. Veg. Crops Res. Bull. 63 (1):25-32.

Górecka K., Cvikrová M., Kowalska U., Eder J., Szafrańska K., Górecki R., Janas K.M.,
2007. The impact of $\mathrm{Cu}$ treatment on phenolic and polyamine levels in plant material regenerated from embryos obtained in anther culture of carrot. Plant Physiol. Biochem. 45:54-61.

Gruca-Królikowska S., Wacławek W., 2006. Metale w środowisku Cz. II. Wpływ metali ciężkich na rośliny. /Metals in the environment Part II. Effect of heavy metals on plants./ Chemia-Dydaktyka-EkologiaMetrologia, 11:1-2. (in Polish)

Jahangir M., Abdel Farid I.B., Coi Y.H., Verpoorte R., 2008. Metal ion-inducing metabolite accumulation in Brassica rapa. J. Plant Physiol. 165:1429-1437.

Janas K.M., Amarowicz R., Zielińska-Tomaszewska J., Kosińska A., Posmyk M.M., 2009. Induction of UV-absorbing compounds in two lentil cultivars with different tolerances to copper ions. Acta Physiol. Plant. 31:587-595.

Johanson G., Shaal L.A., 1957. Accumulation of phenolic substances and ascorbic acid in potato tuber tissue upon injury and their possible role in disease and resistance. Amer. Potato J. 34:200-202.

Joshi A., Kothari S.L., 2007. High copper levels in the medium improves shoot bud differentiation and elongation from the cultured cotyledons of Capsicum annuum L. Plant Cell Tiss. Org. Cult. 88:127-133.

Kothari S.L., Agarwal K., Kumar S., 2004. Inorganic nutrient manipulation for highly improved in vitro plant regeneration in finger millet-Eleusine coracana (L.) Gaertn. In Vitro Cell Dev Biol-Plant, 40:515-519.

Kováčik J., Grúz J., Bačkor M., Tomko J., Strnad M., Repčák M., 2008. Phenolic compounds composition and physiological attributes of $M a$ tricaria chamomilla grown in copper excess. Environ. Exp. Bot., 62:145-152.

Kowalska U., Górecki R., Janas K., Górecki K., 2009. Effect of increased copper concentrations on deformations of the regenerates of carrot obtained from androgenetic embryos. Veget. Crops Res. Bull. 71:1523. DOI: 10.2478/v10032-009-0022-y

Kumar S., Narula A., Sharma M.P., Srivast a v P P.S ., 2003. Effect of copper and zinc on growth, secondary metabolite content and micropropagation of Tinospora cordifolia: A medicinal plant. Phytomorphology, 53:79-91.

Lenartowicz M., 2002. Genetyczna regulacja transportu i metabolizm miedzi. Postępy Biologii Komórki, 29: 221-236. (in Polish)

Maksymiec W., 2007. Signaling responses in plants to heavy metal stress. Acta Physiol. Plant., 29 (3):177-187. DOI: $10.1007 /$ s11738-007-0036-3

Marschner H., 1995. Mineral nutrition of higher plants. second edition. London: Academic Press: 889.

Milić B.L., Djilas S.M., Čanadanović-Brunet J.M., 1998. Antioxidative activity of phenolic compounds on the metal-ion breakdown of lipid peroxidation system. Food Chem. 61:443-447. 
Nirwan R.S., Kothari S.L., 2003. High copper levels improve callus induction and plant regeneration in Sorghum bicolor (L.) Moench. In vitro Cell Dev Biol-Plant, 39:161-164.

Purnhauser L., Gyulai G., 1993. Effect of copper on shoot and root regeneration in wheat, triticale, rape and tobacco tissue cultures. Plant Cell, Tiss. and Org. Cult. 35:131-139.

Rice-Evans C.A., Miller N.J., Paganga G., 1997. Antioxidant properties of phenolic compounds. Trends Plant Sci. 2:152-159.

Saba, Pande D, Iqbal M, Srivastava P.S., 2000. Effect of $\mathrm{ZnSO}_{4}$ and $\mathrm{CuSO}_{4}$ on regeneration and lepidine content in Lepidium sativum L. Biol. Plant, 43:253256.

Sahrawat A K, Chand S., (1999) Stimulatory effect of copper on plant regeneration in indica rice (Oryza sativa L.). J Plant Physiol. 154:517-522.

Singelton Y.L., Rossi J.R., 1965. Colorimetry of total phenolics with phosphomolybdic phosphotungstic acid reagents. Am. J. Enol. Vitic. 16:144-158.

Sinha A., Jain R., Kachhwaha S., Kothari S.L., 2010. Optymalization of the level of micronutrient cooper in the culture medium improves shoot bud regeneration in Indian Ginseng [Withania somnifera (L.) Dunal]. Natl. Acad. Sci. Lett.-India, 33 (1-2):11-16.

Sroka Z., Cis ow ski W., 2003. Hydrogen peroxide scavenging, antioxidant and anti-radical activity of some phenolic acids. Food Chem. Toxicol. 41:753-758.

Tahiliani S., Kothari S.L., 2004. Increased copper content of the medium improves plant regeneration from immature embryo derived callus of wheat (Triticum aestivum). J Plant Biochem. Biotechnol. 13 (1):85-88.

Wojnarowiez G., Jacquard C., Devaux P., Sangwan R.S., Clement C., 2002. Influence of copper sulfate on anther culture in barley (Hordeum vulgare L.) Plant Sci. 162:843-847.

Yruela I., 2005. Toxic Metal In Plants. Copper in plants. Braz. J. Plant Physiol. 17(1):145-156.

Zenk M.H., 1996. Heavy metal detoxification in higher plants - a review. Gene, 179:21-30.

\section{Wpływ podwyższonej zawartości jonów miedzi w pożywce na regenerację zarodków androgenetycznych marchwi (Daucus carota L.)}

\author{
Streszczenie:
}

Badania przeprowadzono $\mathrm{w}$ celu określenia wpływu wyższych stężeń miedzi w pożywce na proces regeneracji zarodków androgenetycznych marchwi odmiany 'Kazan $\mathrm{F}_{1}$ ' uzyskanych w kulturach pylnikowych oraz określenia poziomu rozpuszczalnych fenoli powstałych w regenerantach pod wpływem stresu miedzi. Zazielenione zarodki wykładano na 4 pożywki regeneracyjne B5 ( $\mathrm{G} \mathrm{a} \mathrm{mborg} \mathrm{i} \mathrm{in.}$ 1968) bez hormonów zawierających 0,1 - kontrola; $1 ; 10$; i $100 \mu \mathrm{M} \mathrm{CuSO}_{4} \times 5 \mathrm{H}_{2} \mathrm{O}$. Materiał roślinny przepasażowano 3-krotnie po 4, 9 i 15 tygodniach. Podczas tych pasaży obserwowano powstające struktury, które odpowiednio sklasyfikowano pod względem wzrostu i rozwoju w kulturze in vitro. Analizowano liczbę i masę otrzymanych struktur. W zliofilizowanych regenerantach określono poziom rozpuszczalnych fenoli.

Podwyższone stężenia miedzi w pożywkach regeneracyjnych wpływały korzystnie na powstawanie kompletnych roślin (ukorzenionych rozet) i wtórnych zarodków w trakcie pierwszych 4 tygodni kultury.

Po dłuższym czasie regeneracji (9,15 tygodni) wyższe stężenia miedzi wywoływały negatywne efekty: deformacje rozet. Po 15 tygodniach spadała liczba ukorzenionych rozet.

9-tygodniowa kultura poddana stresowi miedzi wywołała wzrost zawartości fenoli rozpuszczalnych. Najwyższe wartości odnotowano w rozetach traktowanych $10 \mu \mathrm{M} \mathrm{CuSO}_{4}$. Długotrwała ekspozycja na pożywkach zawierających podwyższone stężenia $\mathrm{CuSO}_{4}$ powodowała obniżenie akumulacji związków fenolowych w rozetach. 